\title{
Experience from Traditional Irrigation Management in Ethiopia. Case Study of Holetta River
}

\author{
Getamesay Shiwenzu* \\ Integrated Watershed Management Research, Ethiopian Institute of Agricultural Research, Ethiopia
}

*Corresponding author: Getamesay Shiwenzu, Integrated Watershed Management Research, Ethiopian Institute of Agricultural Research, Ethiopia.
Received Date: May 16, 2019

Published Date: May 29, 2019

Synopsis

The main objective of the study was to assess experience of Holetta River to traditional irrigation users. In the study both qualitative and quantitative research approaches were used. By Purposive and convenient sampling methods open ended questionnaire and unstructured interview were employed along with direct observation. The management of the river very challengeable. Access to water doesn't account for the type of crop and its stage, land hold and distant from the primary channel. Also, farmers make unlawful acts coupled with inefficient application of community the correct the problems. On the other hand, the participation of the community on the efficient management of the river is not effective. Therefore, improving the management of the irrigation is important by involving all concerning bodies. In the future it is imperative to made capacity building effort to enable the community to manage the irrigation system sustainably. Also, policy alternatives have to be tested to insight options for successful community-based irrigation system in the country.

Keywords: Traditional irrigation; Holetta river

\section{Introduction}

Modern irrigation systems were started in Ethiopia during 1960s with the objective of producing industrial crops in Awash Valley. Since then traditional, small, medium and large-scale irrigation has been built [1]. But is the development hindered by the rugged topographic feature of the country coupled with the lack of investment and technical capacity. Further to this except for the river Awash, many of Ethiopia's rivers cross international borders; the water is shared by two or more nations, and this creates significant 'ownership' issues with neighbouring countries [2].

Overall irrigation development of Ethiopia is estimated to be $5-6 \%$ of the developable potential of the 3.7 million ha. The revised figure puts the total irrigated area at about 250,000 hectares. This number gives a per capita irrigated area of about $30 \mathrm{~m} 2$ compared to $450 \mathrm{~m} 2$ global per capita irrigation area [1]. However, based upon the various river basin master plans and land and water resources survey, the gross national irrigation potential would be about 5.3 million hectares and only about 640,000 hectares is irrigated [3].

Traditionalirrigation has a very old history in Ethiopia, especially in some parts of the country like Konso. It has been practiced for centuries in highlands of the country [4]. The traditional irrigation schemes are built under a self-help program carried out by farmers on their own initiative and vary from less than 50 ha to 100ha. Households farm size varies between $0.25 \mathrm{ha}$ and $0.5 \mathrm{ha}$. It encompasses associations comprise up to 200 users who share a main canal or a branch canal [5]. They may be grouped into several teams of 20 to 30 farmers each. Traditional water committees administer the water distribution and coordinate the maintenance activities of the schemes. The total irrigated area under traditional system is estimated to be about 138,000 ha and about 572,000 farmers are involved. Traditional irrigation is also very common in peri-urban areas, particularly in Addis Ababa and Bahir Dar, for the production of vegetables for the local market [6].

The present study aimed at assessing experience of traditional irrigation management at Holetta River in the central highland of Ethiopia. In Holetta town of Madda Guddina village (Kebele), the traditional irrigation user has water user associations with seven committee representatives. To control the water sharing among four stations the committee and users appoints two water dividers in each station. Each station would get water for 48 hours except station four gets 30 hours since which the water moves out of the village. Thus, the research carried out to assess the extent of farmers accessing the water, problems encountered and their participation in irrigation water management practices. Also, it 
tried to see its efficiency and capacity building efforts made so far to the sustainable management of the system and insight for traditional irrigation management in the country.

\section{Methodology}

Holetta is a town in central Ethiopia located in the Oromia region. This town has a latitude and longitude of $9^{\circ} 3^{\prime} 0^{\prime \prime} \mathrm{N} 38^{\circ}$ 30' 0" E, 9.05; 38.5 and an altitude of 2391 meters above sea level.
The town also hosts a research station of the Ethiopian Institute of Agricultural Research founded in 1966; this station is the national center for research to improve the yield of barely, highland oil crops, potatoes, and dairy products. Holetta was the first place in Ethiopia to have a permanent water mill, built in 1909 on the [7]. Currently the town is divided in to 8 kebeles and different governmental and non-governmental institutions [8].

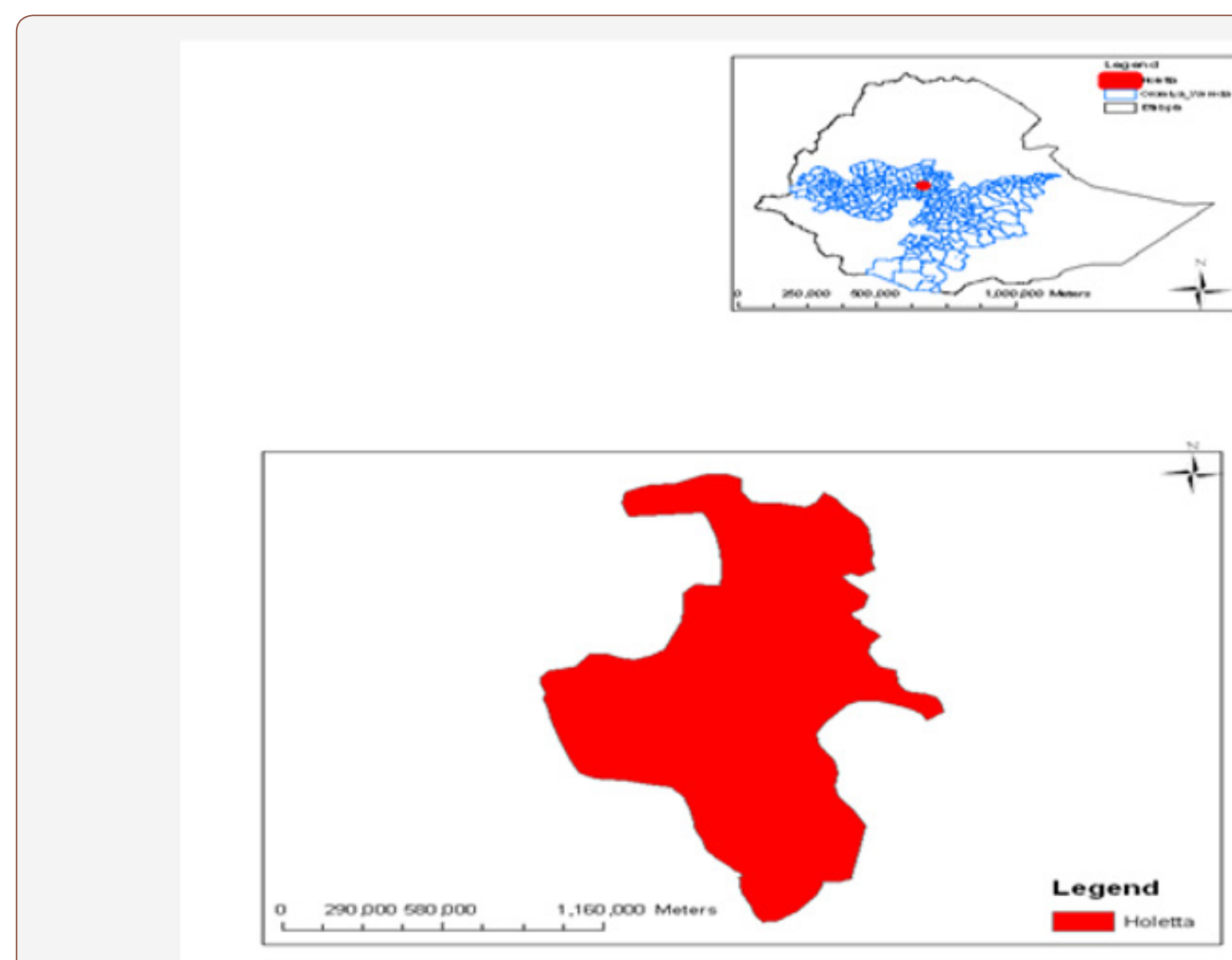

Figure 1: Map of the study area/Holetta.

Based on figures from the Central Statistical Agency (2005), Holetta Genet has an estimated total population of 30,007 (14,825 were men and 15,182 were women) [7]. While from Holetta town [8], in 2010 census the population is 36,705 . In general, Madda Gudina Kebele has 1219 population of which 594 and 625 are male and female, respectively. Holetta River is a perennial river with catchment area of $156 \mathrm{~m} 2$ and $64 \mathrm{~m} 3 / \mathrm{sec}$ of its maximum probable flood discharge from hydrology analysis. There are 145 households who use the river with furrow irrigation to their 100 hectares of land for horticultural and other field crops production. As seen from the command area the farmers have long experience on traditional irrigation cultivating specially potato and they sell their product at Addis Ababa. Beside on the traditional irrigation in Madda Gudina and 03 Kebele, Holetta research center has a command area of 50 hectares that use the river for irrigation by traditional way [8].

The minimum and maximum temperature of the site is with range to 6 and $24{ }^{\circ} \mathrm{C}$ respectively. Annual rainfall is about $1100 \mathrm{~mm}$ and altitudes approaches to $2400 \mathrm{~m}$ and clay loamy/red/ soil exist in the site. From Holetta town administration small scale irrigation project document $[9,10]$, recommended crops are potato, onion, garlic and tomatoes on the first cropping seasons with full irrigation. In second cropping also include cereal, wheat, and barely. The recommendation came from physical and social factors. This study includes one village (Kebele) traditional irrigation users that use Holetta River for agriculture purposes that led by the community through water users' associations. From Schell $[11,19,20]$, a case study is a research method common in social science. It is based on an in-depth investigation of a single individual, group, or event. Due to this the researcher chooses a case study to raise detail and intensive analysis of the community.

Both primary and secondary data sources were utilized in the study. The researcher takes up primary data collected through irrigators and relevant officials at town and kebele level in-person (face-to-face) interviews, questionnaires and direct observation of the site. For interpreting and validating results, combining qualitative and quantitative methods provides a richer, contextual 
basis [12]. Collecting different kinds of data by different methods from different sources provides a wider range of coverage that may result in a fuller picture of the unit under study than would have been achieved otherwise [13,21]. Before the households were selected for survey, the researcher made discussion with irrigation and agronomy expertise and certain households. Among 145 households that cultivate 100 hectare of land, 24 households were purposively selected for the questionnaire survey. Also, from the four irrigation stations, the three stations were selected for the study. The selection of households and stations was dependent on the data from reconnaissance findings. Convenient sampling was used to get 10 respondents for key informant interview to support the questionnaire collected. Five irrigation and agronomy professionals from Holetta town and Wolmera Woreda (district) agriculture office and five water user's committee members from farmers were interviewed. From both categories one female on each had been get for the interview.

The selection of the household for interview from each station was attributed to the researcher perceptions that came from the prior visit to the study area. The respondents from each station were classified and arranged based on the land size and availability of water. It was difficult to include female-head due to the fact that they mostly have rented in/ shared in their plot to others or they hired to their children. But the researcher tried to include almost $20 \%$ from the total interviewed household (Table 1).

Table 1: Total No. of Household, water User Committee (WUC) and Experts Interviewed.

\begin{tabular}{|c|c|c|c|c|c|}
\hline \multirow{2}{*}{$\begin{array}{c}\text { Household/ } \\
\text { Station }\end{array}$} & \multirow{2}{*}{ No } & \multicolumn{2}{|c|}{ Sex } & $\begin{array}{c}\text { Av. Land } \\
\text { Hold /ha }\end{array}$ & $\begin{array}{c}\text { Water } \\
\text { Availability }\end{array}$ \\
\cline { 3 - 6 } & 7 & 5 & 2 & 0.25 & Available \\
\hline 2 & 10 & 10 & 0 & 1 & Shortage \\
\hline 3 & 7 & 4 & 3 & 0.75 & Available \\
\hline WUC Experts & $\mathrm{N}=24$ & & & & \\
\hline & 5 & 4 & 1 & - & - \\
\hline & 5 & 4 & 1 & - & \\
\hline & $\mathrm{N}=10$ & & & & \\
\hline
\end{tabular}

The process of analysis has been carried out by using qualitative description and descriptive statistics. To analyze, the data on social aspects, Statistical Package for Social Science /SPSS/ (Version 17) used. Non-quantifiable data from open-ended questions, key informant interviews, and direct observation have been discussed through qualitative description.

\section{Result and Discussion}

\section{Farmers capacity to manage the irrigation}

The interview result of WUC revealed that out of five respondents three of them witnessed that most farmers cannot manage and control the irrigation water due to the lack of consensus and senses of ownership. In contrary to the above idea the remaining two respondents said that there are farmers which manage and control the irrigation water for its sustainable utilization (Table 2).
Table 2: Access to irrigation water per week/days in hours.

\begin{tabular}{|c|c|c|}
\hline $\begin{array}{c}\text { Access to Irrigation Water per Week/ } \\
\text { Days in hours }\end{array}$ & Frequency & Percent \\
\hline Once a week for unknown hours & 15 & 62.5 \\
\hline Once a week for six hours & 3 & 12.5 \\
\hline Once a week for three hours & 3 & 12.5 \\
\hline Once per ten days for unknown hours & 3 & 12.5 \\
\hline & $\mathrm{N}=24$ & 100 \\
\hline
\end{tabular}

\section{Access to traditional irrigation}

Most of the respondents (62.5\%) are witnessed on they get water once a week for unknown time. Farmers face difficulty to say about the time limit that they get water as the result to varying land size and their locations of land and water applications by them. Though $12.5 \%$ of interviewed said for six hours per a week. Similarly, about 12.5 and $8.2 \%$ of households get water over three hours per week. Due to water shortage and place of land far to the primary channel, farmers may get water per 10 days are suggesting by $12.5 \%$ of the respondent. On the other hand, [14] study showed that income inequality among households with access to irrigation is worse than that of those without access. The implication is that even though accesses to irrigation increased the mean income, farmers have different capacity in making better use of the available irrigation water and therefore irrigation widens the income gap.

\section{Conflict in traditional irrigation}

Amongst surveyed 29.2\% witnessed that there is conflict in the traditional irrigation system. The remaining majority perceived that there is no conflict. From those who said the presence of conflict, four of them said the range of conflict per year is high and others respond it is less (Table 3).

Table 3: Farmer Faced Conflict Related to Irrigation Water.

\begin{tabular}{|c|c|c|}
\hline $\begin{array}{c}\text { Conflict in Traditional Irrigation Water } \\
\text { Management }\end{array}$ & Frequency & Percent \\
\hline $\begin{array}{l}\text { There is no conflict related with irrigation } \\
\text { water management }\end{array}$ & 17 & 70.8 \\
\hline $\begin{array}{c}\text { There is conflict related with irrigation } \\
\text { water management }\end{array}$ & 7 & 29.2 \\
\hline Range of Conflict & $\mathrm{N}=24$ & 100 \\
\hline High range of conflict & 4 & 57.14 \\
\hline Less range of conflict & 3 & 42.86 \\
\hline Water shortage creates conflict & 3 & 42.85 \\
\hline Demanding more water is case for conflict & 2 & 28.57 \\
\hline Displacing of irrigation water & 1 & 14.29 \\
\hline Distributors biased by money & 1 & 14.29 \\
\hline $\begin{array}{l}\text { Hostile activities of the community due to } \\
\text { conflicts over irrigation water }\end{array}$ & Frequency & Percent \\
\hline $\begin{array}{l}\text { Physical confrontation/attack result from } \\
\text { mismanagement of water }\end{array}$ & 14 & 58.3 \\
\hline There is no hostile practice made by farmers & 4 & 16.7 \\
\hline Displace of channel to their field & 2 & 8.3 \\
\hline Removal / damage of farmers field & 2 & 8.3 \\
\hline \multirow[t]{2}{*}{ Death incidence occurred } & 2 & 8.3 \\
\hline & $\mathrm{N}=24$ & 100 \\
\hline
\end{tabular}


The major causes for conflict are water shortage. For causes result from water shortage are account to $42.85 \%$ and increasing in demand for water by farmers also lead to them for disagreement which approach to $28.57 \%$. Farmers also displace the water to their plot without already established program and water divider at some circumstances biased for water distribution by money. For the last two cases farmers respond $14.29 \%$ assuring this. Due to conflict over irrigation water hostile activities by farmers has been practiced. The major actions are physical confrontation/attack result from mismanagement of water and some years before there was death incidence. Also displacing the water, remove cultivation of others cane be mentioned. However, only less number suggest that there is no hostile activity as the result of conflict.
However, it is estimated that a smaller number of conflicts and violation of rules are associated with high proportion of female household headed. This suggests policy intervention is needed to encourage the participation of women in farm, forum and at leadership level in water users' associations and in conflict resolution committee. In addition, effort should make to change the wrong perception of the society towards gender inequality [4].

\section{Farmer participation in irrigation water management aspects}

Concerning irrigation water management $95.58 \%$ of the surveyed households are participate in irrigation users' meeting. However, key informant interviews regard that some time the meeting ends up with disagreement among the participant farmers.

Table 4: Farmers Participation in Irrigation Water Management.

\begin{tabular}{|c|c|c|}
\hline Farmers Level of Participation & Frequency & Percent \\
\hline Farmers participate in irrigation users meeting and orientations & 23 & 95.83 \\
\hline \multirow[t]{2}{*}{ Irrigation user's participation is low in meetings and orientations } & 1 & 4.17 \\
\hline & $\mathrm{N}=24$ & 100 \\
\hline \multicolumn{3}{|l|}{ Frequency of participation in maintenance of irrigation structure } \\
\hline Farmers participation in maintenance of irrigation structures five times per year & 2 & 8.33 \\
\hline They participate four times per year in maintenance of structure & 5 & 20.83 \\
\hline They participate three times per year in maintenance of structure & 7 & 29.17 \\
\hline They participate twice times per year in maintenance of structure & 7 & 29.17 \\
\hline \multirow[t]{2}{*}{ They participate once per year in maintenance of structure } & 3 & 12.5 \\
\hline & $\mathrm{N}=24$ & 100 \\
\hline \multicolumn{3}{|l|}{ Frequency of irrigation structure get damage } \\
\hline The structure gets damage five times per year & 2 & 8.33 \\
\hline The structure gets damage four times per year & 5 & 20.83 \\
\hline The structure gets damage three times per year & 13 & 54.17 \\
\hline The structure gets damage twice per year & 3 & 12.5 \\
\hline \multirow[t]{2}{*}{ The structure gets damage once per year } & 1 & 4.17 \\
\hline & $\mathrm{N}=24$ & 100 \\
\hline \multicolumn{3}{|l|}{ Place of participation on maintenance of irrigation structure } \\
\hline Farmers participate in maintenance of primary canal & 21 & 87.5 \\
\hline \multirow[t]{2}{*}{ Farmer participate in maintenance of canals around their plot } & 3 & 12.5 \\
\hline & $\mathrm{N}=24$ & 100 \\
\hline
\end{tabular}

The damage of the channel and diversion structure is one of a common problem that encounters the irrigation water users of the Madda Guddina village. Similarly, at Raya valley the major problem with traditional irrigation systems is the frequent damage caused by flooding on the traditional diversion weir and irrigation infrastructure. As the result, farmers are engaged in repeated maintenance of these structures [15]. These costs the farmers money and time that could be used for other purposes. The study revealed that mostly channel damage occurs three times every year in the wet seasons. However, the participations of households to the maintenance of the damaged channel are less and this causes the loss of irrigation water that should be used for their farming. Moreover, the farmers' participation for channel maintenance varies from person to person. From the survey $87.5 \%$ of the households participate in the maintenance of the primary channel and proximity to their field (Table 4).

Farmers participate in flood control activities in the summer. The main things that prepare are soil structure and terrace to protect their field and transfer the water into the cannel. In some areas the incidence of flooding is less since they are located far away from the primary channel. During the winter period the channel were cleared as usual which is covered by soil and grass. From observation farmers knowledge to flood control and soil and water conservation measure are less. In contrast study in Awi Zone of Amhara Region claimed that farmers capacity to manage the irrigation system ranging from crop management, irrigation water utilization, gullies control and soil and water conservation is high [16]. 


\section{Efficiency of traditional irrigation}

According to the interviewed five committee members, the four suggesting that the traditional irrigation system is not efficient. The justification for this is always water wastage created in line with taking more time to irrigate. As the result productivity from this are decreased. One farmer excluding the other get difficulty to compare with the modern due to of less knowledge to modern irrigation but believing that if the traditional system managed well could be good.

As shown in (Table 5), Farmers perception towards the efficiency of this irrigation system are low. About $75 \%$ of selected sample household recognize this. However, $25 \%$ of them are confident about its efficiency in different outlooks. The main justifications with of them are confident on there are a possibility of crop cultivation and all users are benefited from it. The reasons behind to the traditional irrigation being not efficient are diverse. The key findings are water wastage created as it goes from stations to stations and from farmers to farmer field. The percentage that point out by farmers are around $37.5 \%$. Recurrent structure damage, flooding and soil erosion are at $37.5 \%$ responded by farmers. The structure is mainly damage by flooding and fastened due to prepared from soil, woods and locally available materials. The canals also covered by grass, soil and waste materials. Similarly, studies in Ethiopia witnessed that efficiency of community-based irrigation schemes is generally low; although, there are efforts, in some donor-funded projects, to develop demonstration trials aimed at improving efficiency [15]. In contrary to this finding at Awi Zone indicated that farmers operating under traditional irrigation schemes are efficient [16]. This will call up an extensive understanding on the typologies of the irrigation and its institutional arrangement is important.

Table 5: Efficiency of Traditional Irrigation.

\begin{tabular}{|c|c|c|}
\hline $\begin{array}{c}\text { Farmer perceptions on the Efficiency of } \\
\text { Traditional Irrigation System }\end{array}$ & Frequency & Percent \\
\hline $\begin{array}{c}\text { Farmers perceived that traditional irrigation } \\
\text { is not efficient }\end{array}$ & 18 & 75 \\
\hline $\begin{array}{c}\text { Farmers perceived that traditional irrigation } \\
\text { is efficient }\end{array}$ & 6 & 25 \\
\hline $\begin{array}{c}\text { Justification for its inefficiency and efficiency } \\
\text { of traditional irrigation }\end{array}$ & $\mathrm{N}=24$ & 100 \\
\hline $\begin{array}{c}\text { it is possible to cultivate, and all benefited } \\
\text { from the irrigation system }\end{array}$ & 6 & 25 \\
\hline $\begin{array}{c}\text { Water wastage encountered due to the water } \\
\text { travels long distance }\end{array}$ & 9 & 37.5 \\
\hline $\begin{array}{c}\text { The irrigation structure is commonly dam- } \\
\text { aged every season }\end{array}$ & 5 & 20.8 \\
\hline Flooding and soil erosion also a problem & 4 & 16.7 \\
\hline & $\mathrm{N}=24$ & \\
\hline
\end{tabular}

\section{Support to farmers in irrigation water management}

The status of support in skill and technical aid to farmer are less. $37.5 \%$ of them replied that now there is some initiation by the town administration and neighboring institutions that use the river for irrigation purpose. Almost at same percent farmers thought that that there is no support. Even with some support still they believe that support does not make a significant change and it is not effective. The community expects that the government has to support them in technical and skill through mobilization activities for better management of the irrigation. Developing local leadership skills for irrigation management also appears to be a key factor for successful collective irrigation management [4].

There are farmers' co-operative organisations in some places providing credit services for WUAs operated communitybased small-scale irrigation schemes [17]. Despite the existing irrigation water user's association (IWUAs), lack of support from different stakeholders has affected their influence in the irrigation development. For instance, the traditionally formed IWUA did not get facilities such as credit and market information because the agricultural policy gives priority to farmers that relay on rain fed agriculture. Generally, farmers also interested to take part in management of the irrigation by using it sustainably without harming it and participate in some acceptable cost to higher the efficiency of the irrigation (Table 6).

Table 6: Support in Traditional Irrigation Management.

\begin{tabular}{|c|c|c|}
\hline $\begin{array}{c}\text { There is no effective support by stakeholders } \\
\text { to manage the irrigation }\end{array}$ & Frequency & Percent \\
\hline $\begin{array}{c}\text { There is some support to manage the } \\
\text { irrigation water }\end{array}$ & 6 & 37.5 \\
\hline $\begin{array}{c}\text { There are some initiations to support the } \\
\text { household to manage the irrigation }\end{array}$ & 9 & 37.5 \\
\hline & $\mathrm{N}=24$ & 100 \\
\hline
\end{tabular}

\section{Conclusion and Recommendation}

\section{Conclusion}

Farmers are not in the position to manage the irrigation water for assuring all and in the sustainable way. In fact, some interest on construction of the new structure has been seen but continuous construction and maintenance activities by some users in the traditional irrigation system doesn't proof their capacity, initiations and agreement of the total. Farmers participate in the irrigation water utilization and management meeting. The meeting is obviously focused on construction and maintenance of the old system. Comparing farmers' participation in the maintenance and construction with structure damage is less. There are also farmers who not involve at all. The place of participation is mainly in the primary channel. From this farmers activity is not practical in the vicinity of their field. The committees also do not supervise each of channels to correct channel widening that result for water wastage. The type of support and skill transformations to farmers from the responsible organ is fewer. There are also no conducive and functional agricultural extension activities. Agricultural technology transformation and dissemination from Holetta research center to the village is not considered. Farmers also have a plan to manage the irrigation by contributing money in acceptable cost to promote the competence of the irrigation.

\section{Recommendation}

The participation of all users is important to improve the management of the river and the irrigation. To overcome this responsible organ has to capacitate the community by training and technical support. Government organ has to work closely 
with the farmers to increase their production by new technology innovations with integration of farmer prior knowledge of water management. Government should take part in empowering activity rather involve in the decisions for the success of community fully take over the irrigation system. But farmers' decision has to be seen from government and responsible organ for its implications. It is possible to higher the efficiency of the irrigation system. Primarily good diversion structure has to be prepared. Also, it is important to transform from open channel to close to improve water productivity. Provision of close channel may be expensive but at least establishing of the channels with local available materials and concrete has to be used. On the other hand, to ensure efficient use farmers has to aware with water saving practice. Instead of over watering their field better to prepare pond storage that may lower water wastage.

Future studies have to focus both technical and social aspects concerning all users. This present study focuses were farmers in Madda Gudina kebele. But in the future water demand from different users may come and without go through all users including institutes in the area and others is not possible to think of on the management of the river in the sustainable way. The study identifies that developing local leadership skills for irrigation management also appears to be a key factor for successful collective irrigation management. General policies and strategies for creating better environment for community-based irrigation system are crucial.

\section{Acknowledgement}

None.

\section{Conflict of Interest}

No conflict of interest.

\section{References}

1. Awulachew SB, Yilma AD, Loulseged M, Loiskandl W, Ayana M (2007) Water Resources and Irrigation Development in Ethiopia. Colombo, Sri Lanka, International Water Management Institute. 78p (Working Paper 123).

2. Berehanu Hailu. 2009. The Impact of Agricultural Policies on Smallholder Innovation Capacities. The Case of Household Level Irrigation Development in Two Communities of Kilte Awlaelo Woreda, Tigray Regional State, Ethiopia. MSc Thesis in Communication and Innovation Studies Group.Wageningen University, Department of Social Science.

3. Haile Tesfay (2008) Impact of Irrigation Development on Poverty Reduction in Northern Ethiopia. A thesis presented to the Department of Food Business and Development in fulfilment of the requirement for the degree of Doctor of Philosophy, National University of Ireland, Cork.

4. Rahel Deribe (2008) Institutional Analysis of Water Management on Communal Irrigation Systems in Ethiopia: The Case of Atsbi Wemberta, Tigray Region and Ada'a Woreda, Oromia Region. A Thesis Submitted to
Addis Ababa University, School of Graduate Studies, Faculty of Business and Economics.

5. Seleshi Bekele Awulachew, Mekonnen Ayana (2011) Performance of Irrigation: An Assessment at Different Scales in Ethiopia. Experimental Agriculture Cambridge journals.

6. Awulachew SB, Merrey DJ, Kamara AB, Van Koppen B, Penning De Vries F, et al. (2005) Experiences and Opportunities for Promoting SmallScale/Micro Irrigation and Rainwater Harvesting for Food Security in Ethiopia. Colombo, Sri Lanka, IWMI. X, 86p. (Working paper 98).

7. Gall Le A (2007) Impacts of Modernization on Traditional Irrigation Schemes, the case of Burkaa Alifif, East Hararghe, Ethiopia. Master of Science thesis in Social Water Management and Tropical Agricultural Development.

8. Holetta Genet Multimedia Information (2010) Internet document.

9. Holetta Town Administration Annual Plan (2011).

10. Holetta Town Administration (2010) Holetta Small Scale Irrigation Projects.

11. Schell C (1992) The Value of the Case Study as a Research Strategy. Manchester, Manchester Business School.

12. Sommer B, Sommer R (1997) A Practical Guide to Behavioral Research: Tools and Techniques. $4^{\text {th }}($ edn), Oxford University Press, Inc, New York.

13. Kaplan B, Duchon D (1988) Combining Qualitative and Quantitative Methods in Information Systems Research: A Case Study. This paper was presented at the Ninth Annual International Conference on Information Systems, Minneapolis, Minnesota. 12(4): 571-586.

14. Namara RE, Makombe G, Hogose F, Awulachwe SB (2007) Rural Poverty \& Inequality in Ethiopia: Can irrigation make a difference. IIPE Workshop, 27-29 Nov 2007, Addis Ababa.

15. Haile Kidane (2009) Community Spate Irrigation in Raya Valley: The Case of three Spate Irrigation Systems. A Thesis Submitted to Addis Ababa University, College of Development Studies, Institute of Regional and Local Development Studies.

16. Temesgen B, Ayalneh B (2005) Technical Efficiency of Resource Use in the Production of Irrigated Potato: A Study of Farmers Using Modern and Traditional Irrigation Schemes in Awi Zone, Ethiopia. Journal of Agriculture and Rural Development in the Tropics and Subtropics 106(1).

17. Mekuria Tafesse (2003) Small-Scale Irrigation for Food Security in SubSaharan Africa, CTA Working Document Number 8031.

18. Lemma Dinku (2004) Smallholders' Irrigation Practices and Issues of Community Management: The Case of Two Irrigation Systems in Eastern Oromia, Ethiopia. A Thesis Submitted to Addis Ababa University, School of Graduate Studies. Institute of Regional and Local Development Studies, Ethiopia.

19. Internet document (2010) Accessed on Dec 28, 2010.

20. Internet document (2011) Accessed on May 30, 2011.

21. Jennifer MB, John DR (2014) Chapter 4 None-experimental Research Methods from Research Methods, Kendall Hunt Publishing.

22. Seleshi BA, Merrey JD (2007) Assessment of Small-Scale Irrigation and Water Harvesting in Ethiopian Agricultural Development. International Water Management Institute (IWMI). 